\title{
Åndsfrihet og tilgivelse - barnehagens «glemte» verdier? Barnehagers arbeid med verdier
}

\begin{abstract}
Av Sissel Mørreaunet og Arve Gunnestad
I denne artikkelen presenteres funn fra en spørreundersøkelse om hvilke av de grunnleggende verdier fra barnehagens formålsparagraf noen utvalgte barnehager har arbeidet spesielt med $i$ løpet av siste år og hvordan de har arbeidet med disse verdiene. Undersøkelsen avdekker at barnehagene arbeider mye med følgende av formålsparagrafens verdier: respekt for menneskeverdet og naturen, nestekjœrlighet, likeverd og solidaritet, mens verdiene åndsfrihet og tilgivelse ser ut til å få langt mindre oppmerksomhet. Vår undersøkelse viser videre at verdiene blir bearbeidet gjennom temaarbeid, spontane samtaler med barna, drøftinger i personalgruppa med vekt på de voksne som rollemodeller og på foreldremøter. I artikkelen diskuteres mulige grunner til at verdiene åndsfrihet og tilgivelse er lite prioritert og i liten grad tematisert $i$ barnehagens arbeid med formålsparagrafens grunnleggende verdier. Funnene drøftes i lys av Taylors teori om the common-ground-strategy og Røviks translasjonsteori.
\end{abstract}

Nøkkelord: Barnehagens formålsparagraf, Verdier, Verdiarbeid i barnehagen, Grunnleggende verdier, Tilgivelse, Åndsfrihet.

\section{Sissel MøRREAUnet, f. 1955, førstelektor, Dronning Mauds Minne Høgskole for barnehagelarerutdanning, Thrond Nergaards vei 7, 7044 Trondheim. E-post: smo@dmmh.no Arve Gunnestad, f. 1951, dosent, Dronning Mauds Minne Høgskole for barnehagelærerutdanning. Adresse: Thrond Nergaards vei 7, 7044 Trondheim. E-post: agu@dmmh.no}

\section{INNLEDNING}

I en tid hvor verdidebatten står sentralt har flere hevdet betydningen av å arbeide med verdier og verdibevissthet sammen med barn og unge (Sagberg, 2012, 2017; Moen, 2017; Sando, 2017; Kjølsvik, 2017; Johansson, 2015; Hovdelien, 2012).

Rammeplan for barnehagen. Innhold og oppgaver ${ }^{1}$ (Kunnskapsdepartementet, 2017a, s.7) slår blant annet fast at «Barnehagens verdigrunnlag skal formidles, praktiseres og oppleves $\mathrm{i}$ alle deler av barnehagens pedagogiske arbeid». Barnehagens verdigrunnlag som nedfelt i formålsparagrafen sier følgende:

Barnehagen skal bygge på grunnleggende verdier $i$ kristen og humanistisk arv og tradisjon, slik som respekt for menneskeverdet og naturen, på åndsfrihet, nestekjærlighet, tilgivelse, likeverd og solidaritet, verdier som kommer til uttrykk $i$ ulike religioner og livssyn og som er forankret i menneskerettighetene (Lov om barnehager \$1 a).

1 Heretter kalt «Rammeplanen $\gg$.

Prismet - IKO-Forlaget 2019

Tilgjengelig på https://journals.uio.no/index.php/prismet. Publisert under CC BY-NC 4.0. Fagfellevurdert 
I Kompetanse for fremtidens barnehage. Revidert strategi for kompetanse og rekruttering 2018-2022 angir Kunnskapsdepartementet «Barnehagens verdigrunnlag» som ett av fire tematiske satsingsområder (Kunnskapsdepartementet, 2017b).

I vår studie undersøker vi hvilke av de grunnleggende verdier fra barnehagens formålsparagraf noen utvalgte barnehager har arbeidet spesielt med i løpet av siste år, og hvordan de har arbeidet med disse verdiene.

I artikkelens første del har vi en kort gjennomgang av tidligere forskning på verdiarbeid i barnehagen før vi presenterer ulike perspektiv på hvordan vi forstår verdibegrepet. Taylor (2007) sin teori forstått som en «felles plattformstrategi» og Røviks translasjonsteori (2007) presenteres som teorigrunnlag for vår drøfting. Deretter gjør vi kort rede for valg av forskningsmetode, før våre funn blir presentert og drøftet.

\section{TidLIGERE FORSKNING PÅ BARNEHAgENS VERDIARBEID}

Det synes å være en $\emptyset$ kende interesse for verdiers betydning for arbeidet $\mathrm{i}$ barnehagen. En gruppe forskere med tilknytning til Universitetet i Stavanger har hatt et større forskningsprosjekt «Verdipedagogikk i barnehagen» (Johansson, Fugelsnes, Mørkeseth, Röthle, Tofteland \& Zachrisen, 2015). Dette prosjektet har gått inn i barnehager, og gjennom intervju og observasjon med barnehagelærere har de sett på hvilke verdier barnehagene har valgt ut og hvordan de arbeider med disse verdiene. De fant fram til en del verdifelt som barnehagene arbeider med, blant andre 1) omsorgsverdier, 2) det demokratiske verdifeltet, 3) det disiplinerende verdifelt, 4) effektivitetsverdier og 5) kompetanseverdier. De konstaterer ut fra sin forskningsgjennomgang at barnehagen er et viktig sted for verdipedagogikk, men at verdilæring og danning fortsatt er ett av de mest fors $\emptyset$ mte områdene i barnehagen (Johansson et al. 2015, s. 17).

Forskningsprosjektet «Verdipedagogikk i barnehagen» unders $\emptyset$ kte først hvilke verdier barnehagene hadde ønske om å arbeide med, for så å se hvordan barnehagene arbeidet med disse verdiene som de selv hadde valgt. Vår studie undersøker imidlertid hvilke av formålsparagrafens verdier barnehagene har arbeidet med foregående år og hvordan barnehagene har arbeidet med disse verdier, altså det sett av verdier som er nedfelt i barnehagens formålsparagraf og som er uttrykk for barnehagens samfunnsmandat.

Artikkelsamlingen Barnehagens grunnsteiner (Glaser, Moen, Mørreaunet og Søbstad, 2018) belyser flere ulike verdier fra barnehagens formålsparagraf. I denne antologien ser Hagesæther på formålsparagrafen ut fra et historisk perspektiv, noe som i denne sammenheng viser at verdier har stått på dagsorden i barnehagen i en årrekke. Tholin retter oppmerksomheten mot omsorg som verdi. Hun peker på at det er få studier relatert til omsorg sammenlignet med fokus på læring. Kibsgaard drøfter solidaritet som verdi ut fra barnehagelæ- 
rerstudenter fra Norge og Nicaragua sin forståelse av begrepet. Mørreaunet redegjør for barnehageansatte sin forståelse av begrepet tilgivelse i barnehagens hverdagsliv. Videre drøfter Kanstad i samme antologi verdiene tillit og respekt knyttet til omsorg og gjensidighet. Dette utgjør eksempler på ulike verdiers betydning og plass $\mathrm{i}$ barnehagens arbeid.

Sagberg (2017) tar i en antologi opp «Mot til å være barnehagelærer», der han peker på verdier som omdreiningspunkt og basis for arbeidet $\mathrm{i}$ barnehagen. Flere forfattere, blant dem Moen, drøfter i denne antologien verdier i forhold til kulturelt mangfold, hva er norske verdier, verdier og ledelse og verdier i etisk lys.

Thoresen (2016) tar også opp verdiarbeid i barnehagen. Hun drøfter ulike verdier, både fra barnehagens formålsparagraf, fra Rammeplanen ${ }^{2}$ og fra de siste offentlige utredningene på området. Hun understreker betydningen av at barnehagen tar samfunnsmandatets verdier uttrykt i formålsparagrafen, på alvor.

Sist, men ikke minst vil vi trekke fram Kunnskapsdepartementets oppnevnte Ekspertgruppe om barnehagelærerrollen (Kunnskapsdepartementet, 2018) sin påpeking av at formålsparagrafens verdigrunnlag er med på å gi retningslinjer for barnehagens innhold og oppgaver. Ifølge ekspertgruppen har barnehagelæreren et stort fortolkningsrom i sin verdiforståelse knyttet til sitt oppdrag om hvordan disse skal formidles og praktiseres. Det er nettopp dette fortolkningsrommet Ekspertutvalget peker på for barnehagepersonalet, som står sentralt for vår unders $\emptyset$ kelse. Hvilke av formålsparagrafens verdier det arbeides med og hvordan det arbeides med disse verdiene, er altså lite unders $\emptyset$ kt ut fra det vi har funnet av annen forskning.

\section{TeoribakgrunN}

Hva er en verdi?

Verdier blir omtalt og definert på flere måter. Verdier beskrives av Van den Heuvel (2001, s.15) som et anker for identiteten vår, et sted vi finner feste. Verdier er med og styrer våre valg og vår atferd, bevisst eller ubevisst. Kirkhaug (2018) sier om verdier at de innehar noen fellestrekk slik som at verdier er relativt varige bevisste og ubevisste ideer, ideologier, standarder, kriterier eller referanser. Slik sett vil de fungere «som et slags underliggende mentalt operativsystem» (Kirkhaug, 2018 s. 21 ). Rokeach (1968) peker på at verdier er preferanser som fører til at en atferd foretrekkes fremfor en annen, eller er preferanser for et $\emptyset$ nsket mål eller slutt-tilstand. Kaasa sier at «Verdier er et lite antall tidløse leveregler som det ikke er nødvendig å argumentere for eller begrunne» (Kaasa, 2004, s. 35).

2 Thoresens drøfting knyttes til 2011-utgaven av Rammeplan for barnehagen. Innhold og oppgaver. 
At vi opptrer vennlig, høflig, respektfullt, medmenneskelig og rettferdig er uttrykk for at verdiene vennlighet, høflighet, respektfullhet, medmenneskelighet og rettferdighet står sentralt i vårt verdigrunnlag. Aadland og Askeland (2017, s. 13) utdyper verdienes funksjon, og hevder at «verdier danner intensjonsgrunnlaget for handling, de skaper retning for handling, og de utgjør fortolkningsgrunnlag i vurdering av handling». Her ser vi at verdier kommer inn både i planlegging, i utføring og i vurdering av handlinger. Verdier kan ikke forstås isolert. Hvordan vi forstår verdiene, og ikke minst - hva vi legger i dem og hvordan de forvaltes, vil være avhengig av den enkeltes ståsted, bakgrunn og tilhørighet. De samme verdiene kan komme til å få ulik betydning avhengig av konteksten de er en del av. Vår forståelse av verdiene og den betydning vi legger i dem, er preget av kultur, religion, samfunnsstruktur og ideologier. Verdioppfatninger og prioritering av verdier er også gjenstand for debatt og endring gjennom historien (Hagesæther, 2018). Noen verdier står sterkere og er mer overbevisende i forhold til hva som er rett og galt for den enkelte. Slike verdier tilegnes tidlig i oppvekst og utdanning og representerer kjerneverdier (Kaufmann \& Kaufmann, 1996).

At en verdi er grunnleggende, slik barnehagens formålsparagraf omtaler dem, betyr at de er av mer fundamental, omfattende og allmenn art. Her er tenkningen at dette er verdier det er stor enighet om (Bostad, 2008). Disse verdiene representerer, slik det er uttrykt i formålsparagrafen, fellesmenneskelige verdier som kommer til uttrykk i ulike religioner og livssyn. Det er forskjell på om en verdi er utbredt og at en verdi er god og som vi dermed vil framelske. Eksempelvis er materialisme eller $\emptyset \mathrm{kt}$ forbruk en meget utbredt verdi, men den er allikevel ikke en verdi barnehage og skole skal bygge på (Sagberg, 2012).

Barnehagenes valg av verdier vil være med å gi bakgrunn for dens pedagogiske plattform og det pedagogiske arbeidet. Våre verdier ligger til grunn for dømmekraften, det faglige skjønnet og kloke valg. Verdigrunnlaget vil danne grunnlag for å hjelpe oss til gode vurderinger i mange ulike valgsituasjoner. Måten vi spontant handler på, vil preges av de verdiene og holdningene vi har utviklet eller som «sitter i kroppen».

\section{I spenningsfeltet mellom religiøsitet og sekularitet}

Barnehagens formålsparagraf har siden vi fikk den første lov om barnehager i 1975, gått gjennom flere endringer når det gjelder verdiforankring. I den reviderte utgaven av 1983 sies det at «Barnehagen skal hjelpe til med å gi barna en oppdragelse i samsvar med kristne grunnverdier». Verdiomfanget utvides i revisjonen av 2010 med å si at barnehagen skal «bygge på grunnleggende verdier i kristen og humanistisk arv og tradisjon, slik som respekt for menneskeverdet og naturen, på åndsfrihet, nestekjærlighet, tilgivelse, likeverd og solidaritet, 
verdier som kommer til uttrykk i ulike religioner og livssyn og som er forankret i menneskerettighetene». Den sentrale begrunnelsen for å endre formålsparagrafen i 2010 var knyttet til utviklingen av et mer sekularisert samfunn som også var preget av kulturelt mangfold (Hovdelien, 2012).

I vår artikkel velger vi å ta utgangspunkt i den kanadiske filosofen Charles Taylor (2007) og hans drøfting av forholdet mellom religion og sekularitet. Taylor (2007) drøfter begrepet sekularitet i forhold til verdier i samfunnet. Han skiller mellom to strategier med hensyn til sekularitet. Den ene er en «hard form» for sekularisering som representerer en «independent political ethic strategy», altså en uavhengig politisk etikk-strategi, som betyr at staten distanserer seg fra alle former for religion. En slik distansering vil kunne innebære en mer religionsfiendtlig ideologi. Den andre kaller han «common ground strategy», en felles-plattform-strategi eller en «myk form» som vektlegger fredelig sameksistens og politisk orden med vekt på menneskerettighetene. Tanken til Taylor er at disse rettighetene vil være mulig å samles om som verdigrunnlag $\mathrm{i}$ et multikulturelt samfunn, på tvers av religiøs eller livssynsmessig tilhørighet (Taylor, 2007).

Hovdelien (2012) drøfter Taylors inndeling og sier at det er denne siste formen, den såkalte «myke sekularisering», den felles plattformstrategien, som kan gjøre det mulig å skape en samlende verdiforankring for fremtidens barnehage på tvers av kulturell tilhørighet (s. 12). Denne felles plattformstrategien bidrar til å åpne opp for at det går an å finne fram til fellesverdier på tvers av ulik religions- og livssynsmessig tilhørighet. Disse fellesverdier vil kunne representere noen felleserfaringer og gi rom for å finne fram til en samfunnsintegrerende kulturell overbygning. Eller som Hovdelien sier: «Bevisstheten om mangfold peker mot nødvendigheten av å ha noe felles» (Hovdelien, 2012, s. 9).

Barnehagens formålsparagraf synes å være et uttrykk for denne «felles plattform-strategien». Barnehagene kan være bidragsytere på veien mot større forståelse for vår kultur og vårt levevis. Det vil være behov for å ha noe felles å stå sammen om i et samfunn som i økende grad består av mennesker med ulik bakgrunn kulturelt, religiøst og politisk.

\section{Formålsparagrafens verdier - behov for oversettelse}

Barnehagens formålsparagraf angir et sett med grunnleggende verdier barnehagene skal bygge sitt pedagogiske arbeid på. Disse verdiene må forstås, bearbeides og oversettes. Her velger vi å trekke veksler på den delen av Røvik (2007) sin teori om translasjon ${ }^{3}$ som knyttes til uthenting av en idé fra et sted (i vår sammenheng: barnehagens formålsparagraf), som skal overføres og mottas

3 Professor i statsvitenskap ved UiT Kjell Arne Røvik har utviklet et teoretisk rammeverk for å forstå og analysere kunnskapsoverføring mellom organisasjoner, som er presentert i boken Trender og translasjoner. Ideer som former det 21. århundrets organisasjon. 
et annet sted (oversettes og tas i bruk i barnehagens praksis). Prosessen å hente ideer ut fra en bestemt kontekst og bringe dem inn i en annen kontekst, kan forstås som en form for oversettelse.

Translasjonsteorien handler om hvordan organisasjoner forholder seg til ideer og oppskrifter og hvilke grep som kan tas for å benytte og håndtere disse. I denne sammenheng er to begrep fra translasjonsteorien sentrale. For det første dekontekstualisering, som handler om hvordan praktiske erfaringer gjennom tidene er oversatt eller har nedfelt seg i dokumenter som barnekonvensjonen og formålsparagrafen. For det andre kontekstualisering, som handler om å oversette ideene til praksis. Altså, en prosess hvor formålsparagrafens verdibegreper oversettes og gjøres praktiske og meningsfulle i barnehagesammenheng.

Slik vi velger å bruke denne teorien, representerer denne prosessen oversettelser eller translasjoner. Disse oversettelsene kan, sier Røvik, ha preg av ulike grader av omforming. En translatør må derfor identifisere både oppskrifter og ideer for å overføre dem til en organisasjon - barnehagen - på en vellykket måte, noe som kan være en krevende oppgave.

Når ideer eller begreper (eksempelvis formålsparagrafens ulike verdier) skal begripes i en organisasjon, må translatøren sette ord på og føre diskusjoner om hva begrepene og ideene kan bety. Det kan bli spørsmål om hvilke oversettelsesmodus som bør velges. Dette vil imidlertid være avhengig av hvor komplekse ideer eller begreper en står overfor. Røvik peker her på tre typer modus for oversettelse. Det første er en reproduserende modus, som betyr at ideen eller begrepet kopieres. Det andre modus oversetteren kan innta, er en modifiserende modus, som innebærer å justere, trekke fra eller legge til, eksemplifisere, konkretisere og drøfte i forhold til forståelse og praksis. Det tredje modus er den radikale modus, som innebærer en radikal forvandling og tilpassing før ideene eller begrepene tas i bruk. I vår sammenheng kan det være interessant å finne ut hvilke moduser for oversettelse trengs for å forstå formålsparagrafens verdier i barnehagen.

Røvik legger vekt på at det kreves en god oversetter for å lykkes med en slik overføring. Oversettelsesarbeidet i vår sammenheng representerer først og fremst en prosess som må foregå i ulike forskningsmiljøer, i Kunnskapsdepartementet og i personalgruppa i den enkelte barnehage gjennom refleksjon, bevisstgjøring og erkjennelser. For å virkeliggjøre verdiene i det daglige arbeidet vil det også kreve innsikt og forståelse både for de verdiene en skal bygge det pedagogiske arbeidet på, og for den sammenhengen de skal føres inn i (barnehagen). Noe også ekspertgruppen om barnehagelærerrollen (2018) peker på når de hevder at barnehagelærerne har et stort fortolkningsrom når de skal prøve ut en rammeplan i praksis og forstå hvordan verdigrunnlaget skal formidles, praktiseres og oppleves $\mathrm{i}$ alle deler av det pedagogiske arbeidet. 


\section{Metode}

Vår unders $\emptyset$ kelse om verdiarbeid i barnehagen har til hensikt å finne svar på noen sentrale spørsmål. Det første spørsmålet vi reiser, knyttes til hvilke av barnehagens grunnleggende verdier fra formålsparagrafen barnehagene prioriterer å arbeide med. Det andre spørsmålet søker svar på hvilke måter barnehagene arbeider med disse verdiene. Vi valgte å bruke spørreskjema fordi vi da kunne få svar fra et større antall barnehager og på den måten å få et visst overblikk over hvilke verdier som blir prioritert og hvordan barnehagene arbeider med verdispørsmål (Johannessen, Tufte og Christoffersen, 2016). Vi benyttet Questbacks nettbaserte teknologi for utsendelse av spørreskjemaene.

Vi har 19 spørsmål i vår undersøkelse hvor vi ønsker å få kunnskap om hvilke verdier som har vært $\mathrm{i}$ fokus siste år i et større antall barnehager, og hvordan barnehagene har arbeidet med disse verdiene. Vi spurte også om verdier har vært tema og hvordan de eventuelt er blitt arbeidet med i personalmøter og i foreldremøter.

I vår undersøkelse er ni av spørsmålene av kvantitativ karakter med på forhånd definerte svaralternativer, og åtte av spørsmålene er oppfølgingsspørsmål der informantene kan gi mer utdypende svar uten på forhånd gitte svarkategorier. For eksempel spørsmål 7: Hvilke av formålsparagrafens grunnverdier blir omtalt i årsplanen i forhold til opplegg i barnehagen siste barnehageår? Her er svaralternativene knyttet til de ulike verdiene i formålsparagrafen. Svarene her er kvantitative i formen og vil gi klare tall for hvor mange av barnehagene som har tatt opp de ulike verdiene. Spørsmål 9 er et fritekstspørsmål: «Utdyp ved eksempel hvordan dere har arbeidet med en eller flere av verdiene ovenfor»». Her er informanten helt fri til å fortelle uten å være bundet til ulike kategorier i sin rapport.

De kvantitative dataene sier noe om barnehagens størrelse, eierforhold og hvilke verdier som blir prioritert, mens svarene på fritekstspørsmålene sier mer om hvordan barnehagene har arbeidet med disse verdiene. En ting er å vite at de fleste av informantene har omtalt formålsparagrafens verdier i årsplanen, men det er pedagogisk også svært interessant å vite hvilke verdier de har prioritert og hvordan de har jobbet med verdiene.

\section{Utvalg}

Spørreskjemaet ble sendt til 170 praksisbarnehager i november 2016. Disse utgjør totalen av antall praksisbarnehager for en barnehagelærerutdanning. Vi valgte å bruke disse barnehagene fordi vi fikk tilgang på adresser, og fordi disse barnehagene representerer et utvalg med en stor variasjon med tanke på størrelse, eierform og driftsform. Utvalget er interessant for høgskolen da det kan være med å gi informasjon om hvordan praksisbarnehager arbeider 
med barnehagens grunnleggende verdier. Av de 170 barnehagene svarte 46 barnehager på undersøkelsen, noe som tilsvarer $27 \%$. I og med at spørreskjemaene ble sendt til barnehagene, er det grunn til å tro at det stort sett er styrere som har svart på vegne av barnehagen. Dette er en lav svarprosent som gir tydelige begrensninger i statistisk generalisering på de kvantitative svarene. Det kan være mange årsaker til at så få har svart. Fra Questbackdataene kan vi se at i tillegg til de 46 som svarte, har 32 åpnet spørreskjemaet, men ikke sendt inn svar. En grunn til at disse 32 ikke har svart, kan være at unders $\emptyset$ kelsen var relativt omfattende med hele 19 spørsmål. En strengere prioritering av antall spørsmål ville nok vært gunstig (Johannessen, Tufte og Christoffersen 2016, s. 262). En annen årsak kan være at styrere som ikke har jobbet med disse verdiene, har kviet seg for å svare fordi de synes det er ubehagelig å innrømme ikke å ha arbeidet med verdier. Mens styrere som arbeider med verdier, er mer tilbøyelig til å svare, både fordi det er lettere å vite hva en skal svare og en vet mer hva det å arbeide med verdier innebærer. Samtidig vet vi at mange av våre praksisbarnehager opplever stort press med tanke på å svare på ulike typer undersøkelser. Vi kan bare spekulere i hva som er årsaken til at mange ikke har svart. Johannessen et al. peker imidlertid på at en svarprosent på 30-40 \% er blitt ganske vanlig på spørreskjemaundersøkelser (2016, s. 247).

Størrelsen på de barnehagene som er representert i utvalget, varierer med tanke på antall barn. I $25 \%$ av barnehagene er det 24-59 barn. I $75 \%$ av barnehagene er det fra 60 til 135 barn. Altså bærer materialet preg av å komme fra relativt store barnehager. Når det gjelder eierforhold var det i vår unders $\emptyset$ kelse var det om lag lik fordeling i antall kommunale (48\%) og private barnehager ( 52 $\%)$. Dette stemmer godt overens med fordelingen mellom private og kommunale barnehager på landsbasis (SSB, Barnehager 2018). Disse tallene gir indikasjon på at utvalget ikke er systematisk skjevt i fordelingen mellom private og kommunale. Med 46 svar kan vi se tendenser til hvilke verdier barnehager jobber mest med og hva som er de mest vanlige måtene å jobbe med verdiene på.

\section{Analysemetode}

Vår analyse av de kvantitative dataene er preget av en enkel frekvensanalyse, det vil si at vi ovenfor har redegjort for barnehagenes størrelse og eierforhold. Hvilke verdier barnehagene har arbeidet med siste år, presenteres i en tabell nedenfor.

Vår analyse av svarene på fritekstspørsmålene representerer en stegvis deduktiv induktiv prosess der vi startet induktivt med analyse av datamaterialet. Vi analyserte svarene med tekstnære koder der vi først noterte ned ord og uttrykk direkte fra respondentenes svar (Tjora, 2017 s. 178 ff). Vi leste gjennom alle svarene flere ganger, og merket oss i første omgang typiske, interessante eller overraskende svar. I den videre analysen prøvde vi å se våre koder i forhold 
til vår hovedproblemstilling om hvordan barnehagen arbeider med verdier, og teorien om oversettelse av mer generelle verdier til barnehagens hverdag. Dette medførte at vi da kunne samordne flere koder til en kategori som uttrykk for de mest sentrale variablene (Nilssen, 2012). I den videre prosessen fant vi å kunne forenkle dataene fra disse spørsmålene til fire kategorier om hvordan barnehagene hadde arbeidet med verdier.

Vi hadde også direkte spørsmål om verdier hadde vært tema på personalmøte og på foreldremøte, og hvordan de hadde jobbet med verdier i disse sammenhengene.

Med hensyn til etiske vurderinger er studien meldt og godkjent av NSD.

\section{Presentasjon av data \\ Hvilke av formålsparagrafens grunnleggende verdier blir omtalt i barnehagens årsplan?}

Våre informanter krysser av for at en eller flere av formålsparagrafens grunnleggende verdier er omtalt i barnehagens årsplan siste barnehageår.

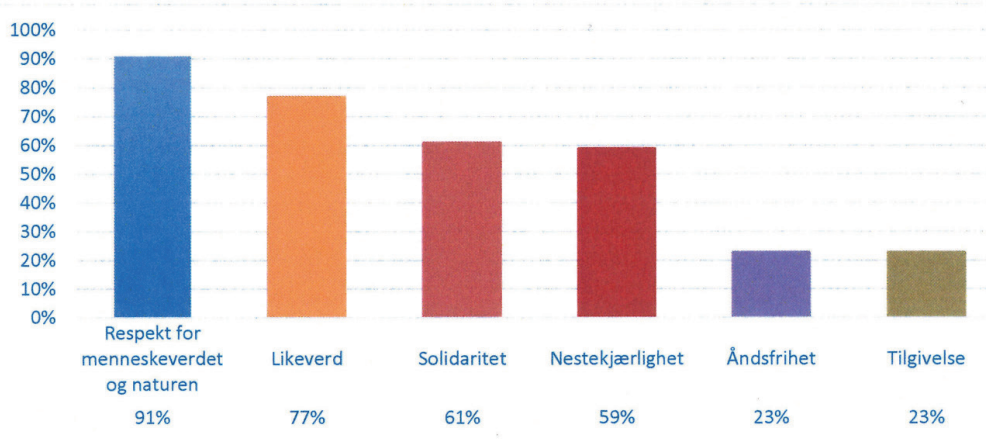

Figur 1: Prosent barnehager som har omtalt de ulike verdier fra formålsparagrafen $i$ sin årsplan siste barnehageår.

Av figur 1 ser vi at hele $91 \%$ oppgir at de har jobbet med «Respekt for menneskeverdet og naturen». Formuleringen i formålsparagrafen setter respekt for menneskeverdet og naturen sammen. Begge er sentrale verdier, men det kan være vanskelig å vite om det er naturvern eller menneskeverdet som har stått i fokus, eller om det er begge deler. Rammeplan for barnehagen understreker menneskeverdet som selve grunnlaget for de andre verdiene.

Videre ser vi av figur 1 at «likeverd» nevnes av $77 \%$. At så mange nevner denne, kan henge sammen med at likeverd er sentral verdi $i$ vårt samfunn. Verdiene «Solidaritet» og «Nestekjærlighet» nevnes av henholdsvis $61 \%$ og $59 \%$. Dette er verdier som går på det å bry seg om hverandre, vise omsorg og dele godene. 
Åndsfrihet nevnes av bare $23 \%$ av barnehagene. Åndsfrihet innbefatter i hovedsak vesentlige sider knyttet til ytringsfrihet, religionsfrihet, informasjonsfrihet og tankefrihet (Høstmælingen, 2012). Både retten til å si sin mening i forhold som angår det, generell ytringsfrihet, retten til religion, samvittighetsfrihet og retten til informasjon er også hjemlet i barnekonvensjonen (FNs konvensjon om barnets rettigheter, 1991).

Tilgivelse omtales også bare i $23 \%$ av barnehagenes årsplaner i vår undersøkelse. Tilgivelse er en prosess og en handling som kommer inn når noen har krenket en annen. Det er en handling som kan gjenopprette en skadet relasjon (Mørreaunet \& Gunnestad, 2013). Vi vil under drøftingskapitlet ta opp hva det kan komme av at disse verdiene nevnes av så få barnehager.

\section{Hvordan barnehagene har arbeidet med verdiene fra formåls - paragrafen}

Respondentene ble bedt om å utdype ved eksempel hvordan de hadde arbeidet med verdiene i formålsparagrafen. Svarene gir interessante synspunkter og eksempler. Vi har kategorisert svarene og kom fram til følgende kategorier:

1 Ulike typer temaarbeid

2 Spontane samtaler med barna i hverdagen

3 Refleksjonssamtaler i personalgruppa med vekt på voksne som rollemodeller

4 Foreldremøter

Ulike typer temaarbeid er den mest brukte arbeidsformen. Flere nevner vennskap som tema, uten å komme mer detaljert inn på hvordan de har arbeidet. En skriver: «Respekt for menneskeverdet og naturen legger vi vekt på i forhold til vårt arbeid med fagområdet natur, miljø og teknikk». Her ser vi at dette temaet og verdiområdet knyttes opp mot et av fagområdene i barnehagens Rammeplan. Her synes «Respekt for menneskeverdet og naturen» å ha et tyngdepunkt mot naturen.

En del barnehager nevner at de tar opp temaer i forbindelse med spesielle dager, årstider eller høytider, f. eks. nevnes FN-dagen. «Barnehagen gjennomf $ø$ rer hvert år prosjekt knyttet til FN-dagen i oktober, med høstmarked og innsamlingsaksjon for barn som ikke har det like godt som oss». Noen barnehager nevner temaer som kommer før høytider eller årstider: «Verdien åndsfrihet og nestekjærlighet løftes frem i desember måned, hvor vi snakker om at ikke alle feirer jul slik etnisk norske gjør». Vi ser at høytider og merkedager gir naturlige utgangspunkt for å ta opp temaer som belyser verdier.

Det er flere som har temaperioder med utgangspunkt i ulike opplegg utviklet av andre. Eksempelvis nevner flere FORUT, en hjelpeorganisasjon som har 
pedagogiske opplegg for barnehager og skoler der barna kan lære om barn i andre land (FORUT, 2000). Opplegget legger vekt på demokrati, solidaritet, toleranse, kulturforskjeller og fordeling av verdens ressurser. Det kan dermed lett kobles opp mot verdiene i formålsparagrafen. En barnehage skriver:

Likeverd og solidaritet: Vi setter av hele oktober hvert år til arbeidet med barneaksjonen FORUT, Vi benytter oss av det pedagogiske materialet fra aksjonen, samt at vi samtaler mye med barna om solidaritet, barns rettigheter, ulikheter i verden og likeverd.

En del barnehager nevner at de er med i Grønt flagg-prosjektet. Dette er en internasjonal miljøsertifisering rettet mot barnehager og skoler med utviklet temaopplegg, videosnutter, spill $\mathrm{mm}$ som skal involvere personalet og barna i miljøforståelse og miljøarbeid. Dette opplegget knytter særlig an til formålsparagrafens «respekt for menneskeverdet og naturen». Både FORUT og Grønt flagg innehar temaer som er mye fremme i media. Noen nevner også «Være sammenmaterialet», et materiell med vekt på relasjonsbygging og tidlig innsats, og ReMida-dagene, et opplegg som er knyttet til senter for kreativt gjenbruk.

I kodegruppen Spontane samtaler med barna i hverdagen fremhever noen av barnehagene at de jobber hele tiden med verdier, det vil si at det er tema som går igjen gjennom året: «Gjennom all pedagogisk virksomhet i barnehagen skal arbeidet med de grunnleggende verdiene ligge «i bånn». En annen skriver:

Vi jobber med flere av de omtalte begrepene i barnehagen, uten at det er konkretisert $i$ årsplanen. Å ta vare på hverandre og naturen rundt oss og jorda vi bor på, er noe vi jobber med daglig. Vi har fokus på relasjoner, på vennskap, inkludering, lcerer om hvordan vi kan ta vare på naturen. Vi fokuserer på gjenbruk ....

En annen svarer: «Vi har likeverd som en av våre tre verdier. Dette arbeides det med i alle sammenhenger i vårt arbeide». Flere styrere peker på at verdiarbeidet ligger under i alt arbeid, det kommer inn i situasjoner som oppstår mellom barn, og mellom barn og voksne, selv om det ikke står nevnt i årsplanen.

Refleksjonssamtaler i personalgruppa med vekt på voksne som rollemodeller er av de mest vanlige måtene barnehagene i vår unders $\emptyset$ kelse har jobbet med verdiene i formålsparagrafen. En styrer skriver:

Vi reflekterer over praksis systematisk gjennom hele året. Vi ser på praksis opp mot formuleringer i formålsparagrafen og spør i forhold til begrepene vi finner der.

Flere knytter kommentarer til rammeplanen:

Vi har likeverd som en av våre tre verdier ... Vi har en progresjonsplan som følger Rammeplanens fagområder og der er våre verdier og relasjonsmål synliggjort. Dette dokumenteres hver måned.

Flere av barnehagene synes å ha en løpende drøfting av verdier relatert til formåls- 
paragrafen og rammeplanen. En barnehage har utarbeidet en verdihåndbok for barnehagen. Denne beskriver forventet atferd av de voksne i arbeidet med barna. En annen forteller at de har laget en progresjonsplan for fagområdene i årsplanen der verdier kommer tydelig fram. Barnehagepersonalet reflekterer fortløpende over de verdier som kommer til uttrykk i praksisfortellinger. Det arbeides med hele personalgruppa på personalmøter og planleggingsdager over lang tid hvor lesesirkler og refleksjonssamtaler tas i bruk.

Når styrerne kommenterer arbeidet med verdier i personalgruppa, knyttes dette ofte til en forventning av voksne som modeller for barna:

Den aller viktigste faktor for verdiformidling er de voksne som jobber i barnehagen. Den innstillingen de har til barn, hvordan de går frem når de løser konflikter og i hvor stor grad de klarer å ha en anerkjennende holdning til alle barn. Barn gjør det vi gjør, og ikke nødvendigvis det vi sier. Derfor er verdiarbeid helt grunnleggende for vår profesjon og må ligge som et grunnlag for yrkesutøvelsen.

Flere av styrerne understreker at personalet som rollemodeller er den viktigste faktoren i verdiarbeidet i barnehagen. Dette forutsetter at verdiarbeidet blir forankret i personalgruppa før man kan ta det med barna. En styrer understreker betydningen av voksenrollen og refleksjon i personalgruppa:

Vi ønsker at verdiene skal vare forankret $i$ alle i personalgruppa. Verdiene må dekonstrueres og reflekteres rundt slik at de har det samme innholdet for alle. Verdiene er derfor alltid med når vi reflekterer på møter. Enten det gjelder prosjektarbeid eller hverdagssituasjoner. Det er viktig å se på voksenrollen - gjør vi det vi sier vi skal gjøre?

Uttalelsene understreker nettopp refleksjonens og drøftingenes betydning av verdiene i personalgruppa som grunnlag for lærerne som gode modeller.

Foreldremøter representerer den siste kodegruppen for måter å arbeide med de grunnleggende verdiene. På spørsmål om barnehagene har hatt verdier som tema på et foreldremøte siste år, svarer $65 \%$ ja. Med tanke på at det ikke er mange foreldremøter i løpet av ett år, er dette et tall som viser at barnehagene prioriterer og ser viktigheten av å involvere foreldrene i arbeid med verdier.

På et åpent spørsmål om hvordan de har jobbet med verdier med foreldrene, nevner mange at foreldrene involveres i gruppedrøftinger om verdier. En skriver: «Foreldrene arbeidet i grupper, innspill ble notert ned og sendt ut til hele foreldregruppa». Andre nevner foreldremøter med intern eller ekstern innleder og deretter drøfting i grupper: «Vårens foreldremøte hadde tema om mobbing. Ekstern innleder og refleksjon etterpå. Utfordret foreldrenes ansvar som forbilder for barna». Dette med foreldrene som rollemodeller går igjen hos flere. En styrer bruker flere måter for å involvere foreldrene i verdiarbeid: «Vi gir ut månedsbrev med våre prosjekter, foreldremøter ... Hjemmeside ... 
Foreldresamtaler med bilder og film. Daglig leder deler tanker på mail ... f. eks. om lekeslåssing». Vi ser at styrerne aktivt involverer foreldrene i barnehagens verdiarbeid i foreldremøter og temamøter, ofte med gruppearbeid, men også gjennom andre kommunikasjonsmåter.

\section{Drøfting}

\section{Hvilke av formålsparagrafens verdier har barnehagene arbeidet med?}

Vi antar at barnehagens valg av fokusverdier kan knyttes til mange ulike forståelser og begrunnelser. Om vi ser på barnehagens rammeplan, så understreker den menneskeverdet som selve grunnlaget for de andre verdiene. Respekt for naturen er også i sterk grad vektlagt i barnehagens Rammeplan, både i verdien «bærekraftig utvikling» og i et eget fagområde. Tematikken gis stor oppmerksomhet både i media og i politikken.

Generelt ser det også ut til at respekt i seg selv representerer en viktig verdi for mange i barnehagen. Respekt nevnes av svært mange når vi i vår studie spør om det er andre verdier enn formålsparagrafens grunnleggende verdier de har omtalt i årsplanen siste barnehageår. Moens studie (2017) bekrefter at både foreldre og ansatte anser verdien respekt for å ha svært stor betydning. Hun peker at dette dreier seg om respekt i form av å vise respekt i forhold til åpenhet og aksept for hverandre, for ulikhet og mangfold, inkludering og anerkjennelse (Moen, 2017).

Videre ser vi at «Likeverd» får høy skår. Likeverdet står også sterkt og er sentralt i vårt samfunn. Vi tenker her blant annet på likeverd mellom gutter og jenter, mellom barn med ulik etnisk bakgrunn og i forhold til barn med ulike funksjonsnedsettelser. Dette tydeliggjøres i barnehagens rammeplan og i den generelle debatten i samfunnet. Solidaritet og nestekjærlighet knyttes til verdier som går på det å bry seg om hverandre, vise omsorg og dele godene. Det er verdier som står sentralt i barnehagetradisjonen, og i norsk kultur.

Relatert til Taylor (2007) sin teori om common-ground strategy - altså en felles plattform-strategi for valg av verdier, er verdiene $\mathrm{i}$ barnehagens årsplaner verdier det kan være lett å enes om for både ansatte og foreldre. Ifølge Hovdelien (2012) representerer alle formålsparagrafens grunnleggende verdier denne felles plattformen og vil kunne være mulig å samles om i et multikulturelt samfunn. Ikke alle verdier i barnehagens formålsparagraf, eksempelvis åndsfrihet og tilgivelse, ser ut til å være like lett å «oversette» til barnehagens praksis og deres arbeide med verdier. Når barnehagenes verdiarbeid utfordres også av verdier de kanskje opplever som mer krevende eller som de har et mer distansert forhold til, eller som kan være vanskelig å «oversette», så får de mindre oppmerksomhet. Som tidligere nevnt peker Røvik (2007) på at overset- 
telse krever både mot, kunnskap, tålmodighet, styrke og innsikt. En kan tenke seg at verdiene tilgivelse og åndsfrihet kan forbindes med noe litt mer ukjent og kanskje ubearbeidet, og kanskje derfor i langt mindre grad er tatt med inn $\mathrm{i}$ barnehagens hverdag. Vi har tidligere vist at $23 \%$ av barnehagene oppgir at de har arbeidet med disse verdiene.

I en intervjuunders $\emptyset$ kelse om barnehagepersonalets forståelse av tilgivelse går det nettopp fram at enkelte opplever dette som et vanskelig og fjernt begrep (Mørreaunet, 2018). Tilgivelse er imidlertid en sentral verdi i forhold til å fremme fellesskap og reparere relasjoner både mellom barn, mellom voksne og barn og mellom voksne (f.eks. i familieterapi). Det har også fătt $\emptyset$ kende betydning på det politiske plan, for eksempel gjennom forsoningsprosessen i Sør-Afrika, og i Norge gjennom statsministres unnskyldning til norske jøder, til taterne og nylig til «tysker-tøsene» for overgrep fra det norske samfunnet. Det blir da viktig å ta det oversettelsesarbeidet som er nødvendig i personalgruppa, i foreldregruppa og i temaarbeid med barna for å kunne praktisere denne verdien i barnehagen.

Åndsfrihet nevnes også av omtrent en fjerdedel av barnehagene. Åndsfrihet innbefatter vesentlige sider knyttet til ytringsfrihet, informasjonsfrihet, religionsfrihet, og tankefrihet (Høstmælingen, 2012). Både retten til å si sin mening og bli hørt i forhold som angår det, retten til religion, samvittighetsfrihet og retten til informasjon er også hjemlet i Barnekonvensjonen (FNs konvensjon om barnets rettigheter, 1991). På samme måte som tilgivelse tror vi dette kan henge sammen med at barnehageansatte også finner denne verdien komplisert å «oversette» til konkret arbeid. I internasjonal sammenheng ser vi at likeverd, ytringsfrihet, samvittighetsfrihet og religionsfrihet utfordres i mange land. Med $\emptyset$ kende innvandring kan dette bli verdier som kan bli enda viktigere å jobbe med. Begrepet «medvirkning» har nær tilknytning til ytringsfrihet, og kan slik sett sees som en del av åndsfrihet. Medvirkning ${ }^{4}$ som verdi har også kommet fra et overordnet nivå, nemlig fra Barnekonvensjonen til Rammeplan for barnehagen. Medvirkning har vært gjenstand for et massivt oversettelsesarbeid gjennom ulike prosjekter med eksemplifisering, konkretisering og faglig drøfting både i barnehagelærerutdanningen og i barnehagen (Wolf \& Svenning, 2018).

Rammeplanen (Kunnskapsdepartementet, 2017a, s. 7) siterer under «Barnehagens verdigrunnlag» formålsparagrafen for barnehagen, og følger opp med at «Alle barnehager skal bygge på verdigrunnlaget som er fastsatt i barnehageloven ...». Men etter dette utdyper og kommenterer den følgende verdier: Barn og barndom, Demokrati, Mangfold og Gjensidig respekt, Likestilling og likeverd, Bærekraftig utvikling og Livsmestring og helse. Det er her påfallende at flere

4 Medvirkning er et tema barnehagene har arbeidet mye med. NFRs forsknings- og utviklingsprosjekt Barns medvirkning i et relasjonelt perspektiv - fokus på de yngste barna i barnehagen (Bae, 2012, red.) er et eksempel på dette. Temahefte om barns medvirkning (Kunnskapsdepartementet, 2006) er et annet eksempel. Videre er det flere utgivelser knyttet til barns medvirkning. 
av verdiene i det lovbestemte formålet ikke blir nevnt, deriblant åndsfrihet og tilgivelse. Kunnskapsdepartementets kompetansestrategi for barnehagen (Kunnskapsdepartementet, 2017b) vektlegger barnehagens verdigrunnlag som ett av fire satsingsområder. Også her utelates verdiene åndsfrihet og tilgivelse i lista over aktuelle verdier som man da kan jobbe med (Kunnskapsdepartementet, 2017 s. 17-18). I forhold til Røviks (2007) ulike modus for oversettelse kan det synes som Rammeplanen og Kunnskapsdepartementets kompetansestrategi bare har brukt en reproduserende modus i forhold til formålsparagrafen uten noe videre eksemplifisering, konkretisering og drøfting av hvordan disse verdiene kan oversettes til barnehagens hverdag. Dette kan også være noe av forklaringen på at disse verdiene ikke har fătt den oppmerksomhet de skulle hatt som en verdi i barnehagens samfunnsmandat.

Røviks translasjonsteori er med å sette verdiarbeid i et viktig perspektiv med tanke på å arbeide aktivt med oversettelser. Rammeplan for barnehagen pålegger barnehagen å arbeide i tråd med formålsparagrafens grunnleggende verdier (Kunnskapsdepartementet, 2017). Skal barnehagene lykkes med intensjonen om at barnehagens verdigrunnlag skal formidles, praktiseres og oppleves i alle deler av barnehagens pedagogiske arbeid, vil det kreve stor grad av translat $\varnothing r-$ kompetanse. Å oversette alle formålsparagrafens verdier, også de minst omtalte, vil kreve en oversettelse ut over en reproduserende modus. En modifiserende modus vil kunne bidra til at ideen eller begrepet konkretiseres, eksemplifiseres og drøftes. Et radikalt oversettelsesmodus vil kunne bidra til at begrepene blir omdannet og får sitt eget barnehagefaglige innhold. Når det gjelder verdiene åndsfrihet og tilgivelse, kan det være at en radikal oversettelsesmodus bør tas i bruk for at disse verdiene skal bli meningsfulle i barnehagesammenheng.

\section{Hvordan barnehagene arbeider med verdier}

Den vanligste måten styrerne svarer at de arbeider med verdier, er gjennom tema-arbeider. Her kan en verdi være tema, for eksempel respekt for menneskeverdet og naturen eller likeverd. Det kan også være temaer som aktualiserer verdier, for eksempel mobbing som kan belyse verdier som omsorg, nestekjærlighet og solidaritet. Noen temaer er relatert til årstider, høytider og merkedager. 1. mai, 17. mai, FN-dagen, jul, Id, påske og andre dager kan være naturlige og interessante innfallsvinkler til verdier som likeverd og samarbeid, demokrati, åndsfrihet, solidaritet, nestekjærlighet, fellesskap og tilgivelse.

Svært mange av svarene viser at bearbeiding av verdiene i personalet er en viktig måte å jobbe med verdier. Å ta opp en verdi som et tema med barna forutsetter at voksne har en klar og positiv forståelse av hva den verdien betyr og hvordan den virker inn i vårt daglige liv. Hele personalgruppen trenger å oversette og reflektere over verdiens betydning og mening. Dette kom tydelig 
fram i en unders $ø$ kelse om verdien tilgivelse i barnehager i Swaziland, Kenya og Norge gjennomført av Gunnestad, Mørreaunet \& Onyango (2015). Etter samtaler om tilgivelse i personalet på forhånd kom det i denne unders $\emptyset$ kelsen fram flere refleksjoner i sammenheng med at det hadde vært viktig at personalet selv fikk refleksjoner over egne erfaringer av konflikt og tilgivelse. Dette førte til en dypere forståelse også av barnas prosesser, for eksempel at man ikke bare kan forlange at barn skal tilgi hverandre, men at man noen ganger må gi barn tid til å tilgi, og at tilgivelse bygger på en erkjennelse både fra den som ber om tilgivelse og den som tilgir.

Flere av svarene barnehagene gir, peker på personalet som rollemodeller som den viktigste måten barn kan lære om verdier. Barn trenger å se voksne som praktiserer verdiene seg imellom, overfor barn og i deres måte å hjelpe barn å løse sine konflikter. Barn lærer ved å se hvordan voksne snakker til hverandre og oppfører seg mot andre. Mange ser det da også som viktig å ha verdier som tema på personalmøte ( $80 \%$ ). Drøftinger med utgangspunkt i bilder, hverdagssituasjoner eller praksisfortellinger blir fremhevet. Å arbeide med oversettelser, kontekstualisering av verdier fra formålsparagraf til praksis, fordrer tid og rom for refleksjon og bearbeiding. Det er hvordan personalet forstår og kan oversette verdiene på dette nivået til praktisk handling i barnehagen, som avgjør hvordan barna får med seg verdiene i sitt eget liv.

Vår undersøkelse viser også at «spontane samtaler med barn i hverdagen» er foretrukket som arbeidsform i arbeidet med verdier. Flere understreker at verdiene ligger til grunn for alt de gjør i barnehagen. Hverdagen er full av episoder og situasjoner der verdier som likeverd, tilgivelse, solidaritet, åndsfrihet, respekt osv. kan bli eksemplifisert og brukt for å forstå og løse situasjoner som er vanskelige. At personalet har jobbet med verdiene selv, og barna har jobbet med dem i tema eller prosjekt, gjør de spontane samtalene mer innholdsrike og forståelige (Mørreaunet \& Gunnestad, 2013).

I undersøkelsen vår angir mange at de også har tatt opp verditemaer på foreldremøter. Å trekke inn foreldrene i verdiarbeidet er viktig for at ikke barna skal komme i skvis mellom ulikt verdisyn mellom hjem og barnehage (Gunnestad, 2019). Vi vil også hevde at det er viktig med tanke på overføring av læring til barnets liv utenfor barnehagen og som en videreføring etter barnehagen.

I Stavanger-studien (Johansson et al. 2015) kommer en del av de samme arbeidsmåtene frem. Prosjektet observerte særlig hvordan verdier kommer til uttrykk og blir formidlet i uformelle situasjoner i garderoben og i lek. Videre at drøftinger i personalgruppa har vært viktige, ofte med utgangspunkt i praksisfortellinger, men også i temaer om verdier og verdiformidling på refleksjonsseminarer og inspirasjonsdager. Temaperioder knyttet til spesifikke temaer og arbeid rettet mot foreldrene har ikke fokus i Stavangerstudien. 
I vår undersøkelse ser vi hvordan disse fire arbeidsmåtene i forhold til verdier er avhengig av hverandre. Tema-arbeider $\mathrm{i}$ relasjon til verdier forutsetter at personalet har hatt en prosess der de har fått drøfte og reflektere over verdiene. Dette gjør det mer naturlig å praktisere og leve verdiene i det daglige arbeidet. Når personalet har deltatt i denne typen oversettelsesprosess, kan de ta dette opp på en måte som kan bli meningsfull og spennende for barna (Røvik, 2007). At verdiene blir gitt rom og tid til bearbeiding gjennom et temaarbeid i barnehagen, gir barna en mulighet til å få en dypere forståelse for verdiene både intellektuelt og følelsesmessig (Gunnestad, Mørreaunet og Onyango, 2015). Når ansatte og barn senere også kan referere til verdiene, tematisere og praktisere dem i mange ulike situasjoner i løpet av året i barnehagen, får barnas begreper og forståelse mulighet for å utdypes og utvikles videre. Når så foreldrene har fått del i denne forberedelsesprosessen, vil det kunne føre til et samarbeid om verdier som gir et helhetlig oppdragelsesmiljø i tråd med Rammeplanen for barnehagen - innhold og oppgaver (Kunnskapsdepartementet, 2017a).

\section{Avslutning}

Denne studien viser at barnehagene er engasjert i arbeid med verdier. Verdiene respekt for menneskeverdet og naturen, nestekjærlighet, likeverd og solidaritet, er på mange måter både et uttrykk for sentrale dimensjoner i vår nordiske barnehagetradisjon og verdier som det er arbeidet mye med, oversatt og forstått som sentrale. Slik sett vil de representere en felles plattform for hva ansatte og foreldre kan enes om er viktig å arbeide med. Få av disse verdiene har en kontroversiell valør i det norske samfunnet.

Det kommer klart fram at verdiene tilgivelse og åndsfrihet i liten grad omtales i barnehagenes årsplaner, noe vi mener kan skyldes at disse verdiene $\mathrm{i}$ liten grad er bearbeidet og oversatt slik de øvrige verdiene har blitt. Det kan også ha sammenheng med at disse verdiene ikke blir nærmere omtalt og konkretisert i Rammeplan for barnehagen.

Vårt funn peker på at barnehagens pedagogiske ledelse står i en situasjon der Rammeplanen sier at «barnehagens verdigrunnlag skal formidles, praktiseres og oppleves i alle deler av barnehagens pedagogiske arbeid» samtidig som den samme planen gir lite støtte i eksemplifisering, konkretisering og drøfting av en del av disse verdiene. I dette ligger en utfordring spesielt med tanke på å finne gode oversettelser for verdiene åndsfrihet og tilgivelse.

Vår unders $\emptyset$ kelse viser også at barnehagene arbeider med verdier på varierte måter. I en tid med økende mangfold i befolkningen vil det være viktig å identifisere fellesverdier. Da blir det viktig at aktører på ulike nivå (departement, utdanningsinstitusjoner og barnehager) deltar i den oversettelsesprosessen som er nødvendig med eksemplifisering, konkretisering og drøfting av disse verdiene slik at de kan bli forstått og praktisert mellom barn og personale i barnehagen. 


\section{LITTERATUR}

Aadland, E. \& Askeland, H. (2017). Verdibevisst ledelse. Oslo: Cappelen Damm Akademisk. Bae, B. (2012). «Barnehagebarns medvirkning. Overordnede perspektiver og internasjonal forankring.» i Bae, B. (red.) Medvirkning i barnehagen. Potensialer i det uforutsette. Bergen: Fagbokforlaget.

Bostad, I. (2008). «Synlige verdier og usynlig dobbeltmoral» i O. Leirvik \& $\AA$. Røthing (red.) Verdier. Oslo: Universitetsforlaget.

Dahl, E. (2009). Om Charles Taylors «A Secular Age». Kirke og Kultur 1/2009. s.63-68, https://www.idunn.no/kok/2009/01/om_charles_taylors_asecular_age.

FNs konvensjon om barnets rettigheter. (1991). Oslo: Barne- og Familiedepartementet.

FORUT, S. (2000). Under Afrikas sol. Et aktivitetsopplegg fra FORUT. For 1. til 4. klasse [Elevoppgaver]. Gjøvik: FORUT, Solidaritetsaksjon for utvikling.

Gunnestad, A. (2019). Didaktikk for barnehagelcerere. En innføring. 2. utgave. Oslo: Universitetsforlaget.

Gunnestad, A., Mørreaunet, S \& Onyango, S. (2015). «An International Perspective on Value Learning in the Kindergarten - Exemplified by the Value Forgiveness » i Early Child Development and Care, 185, no.11-12, s.1894-1911. doi:10.1080/030044 30.2015.1028384

Hagesæther, G (2018). «Barnehagens formål i et historisk perspektiv» i: V. Glaser, K.H. Moen, S. Mørreaunet \& F. Søbstad: Barnehagens grunnsteiner. Formålet med barnehagen. 2. utgave. Oslo: Universitetsforlaget.

Hovdelien, O. (2012). «Barnehagens formålsparagraf - hvordan skal den forstås?» i Prismet 2-3/2012. s. 5-13.Oslo: IKO-Forlaget. https://oda.hio.no/jspui/ bitstream/10642/1815/1/959655.pdf

Høstmælingen, N., Kjørholt, E.S., \& Sandberg, K. (2016). Barnekonvensjonen. Barns rettigheter i Norge. Oslo: Universitetsforlaget.

Høstmælingen, N. (2012). Sivile rettigheter og friheter (s. [119] -139). Oslo: Universitetsforlaget.

Johannessen, A., Tufte, P.A. \& Christoffersen, L. (2016). Introduksjon til samfunnsvitenskapelig metode. Oslo: Abstrakt forlag.

Johansson, E., Fugelsnes, K., Mørkeseth, E.I., Röthle, M., Tofteland, B. \& Zachrisen, B. (2015). Verdipedagogikk i barnehagen. Oslo: Universitetsforlaget.

Kanstad, M. (2018). «Gjensidighet i tillit og respekt» i V. Glaser, K.H. Moen, S. Mørreaunet \& F. Søbstad: Barnehagens grunnsteiner. Formålet med barnehagen. 2. utgave. Oslo: Universitetsforlaget.

Kaufmann, G. \& Kaufmann, A. (1996). Psykologi i organisasjon og ledelse. Bergen: Fagbokforlaget.

Kibsgaard, S. (2018). «Solidaritet i pedagogisk arbeid» i V. Glaser, K.H. Moen, S. Mørreaunet \& F. Søbstad: Barnehagens grunnsteiner. Formålet med barnehagen 2. utgave. Oslo: Universitetsforlaget. 
Kirkhaug, R. (2018). Verdibasert ledelse. Oslo: Universitetsforlaget.

Kjølsvik, I. (2017). «Norske verdier for norske barnehager - og kildene til dem» i

S. Sagberg (red.) Mot til å være barnehagelærer. Med verdier som omdreiningspunkt. Bergen: Fagbokforlaget.

Kunnskapsdepartementet (2018). Barnehagelcererrollen $i$ et profesjonsperspektiv - et kunnskapsgrunnlag. Ekspertgruppen om barnehagelcererrollen. Oslo

Kunnskapsdepartementet (2017a). Rammeplan for barnehagens innhold og oppgaver. Oslo: Kunnskapsdepartementet.

Kunnskapsdepartementet (2017b). Kompetanse for framtidens barnehage. Revidert strategi for kompetanse og rekruttering 2018-2022. Oslo

Kunnskapsdepartementet (2006): Temahefte om barns medvirkning.

Kaasa, K. (2004). Kvalitet $i$ helse- og sosialtjenesten. Det er menneskene det kommer an på. Oslo: Gyldendal Akademisk.

Leirvik, O. \& Røthing, A. (2008). Verdier. Oslo: Universitetsforlaget.

Meld.St.24 (2012-2013) Melding til Stortinget. Framtidens barnehage. Oslo: Kunnskapsdepartementet.

Moen, K.(2017). «Mot til å formidle verdier - også i et kulturelt mangfold» i S. Sagberg (red.) Mot til å vare barnehagelcerer. Verdier som omdreiningspunkt. Bergen: Fagbokforlaget.

Mørreaunet, S. og Gunnestad, A. «Tilgivelse i barnehagen - et internasjonalt perspektiv» i Prismet, nr. 1/2013. s.3-18. Oslo: IKO-Forlaget.

Mørreaunet, S. (2018). «Tilgivelse - del av barnehagens praksis?» i: V. Glaser, K.H. Moen, S. Mørreaunet \& F. Søbstad: Barnehagens grunnsteiner. Formålet med barnehagen. 2. utgave. Oslo: Universitetsforlaget.

Nilssen, V. (2012). Analyse i kvalitative studier. Den skrivende forskeren. Oslo: Universitetsforlaget.

NOU 2007:6 Formål for framtida. Formål for barnehagen og oppleringen.

Rammeplan for barnehagens innhold og oppgaver (2017a). Oslo: Kunnskapsdepartementet

Ringdal, K. (2013). Enhet og mangfold. Samfunnsvitenskapelig forskning og kvantitativ metode (3. utg. ed.). Bergen: Fagbokforlaget.

Rokeach, M. (1968). Beliefs, attitudes and values. London: Jossey-Bass Publishers.

Røvik, K.A. (2007). Trender og translasjoner. Ideer som former det 21.århundrets organisasjon. Oslo: Universitetsforlaget.

Sagberg, S. (2012). Religion, verdier og danning. Barns møte med de store spørsmål i livet. Bergen: Fagbokforlaget.

Sagberg, S. (red. 2017). Mot til å vœre barnehagelærer. Verdier som omdreiningspunkt. Bergen: Fagbokforlaget.

Sagberg, S. (2017). «Etikk i et verdimessig ingenmannsland» i S. Sagberg (red.) Mot til å være barnehagelorer. Verdier som omdreiningspunkt. Bergen: Fagbokforlaget. 
Sando, S. (2017). «Mot til å stå i det ufullkomne» i S. Sagberg (red.) Mot til å være barnehagelarer. Verdier som omdreiningspunkt. Bergen: Fagbokforlaget.

Taylor, C. (2007). A Secular Age. Cambridge, Massachusetts; London: The Belknap Press of Harvard University Press.

Tholin, K.R. (2018). «Omsorg usynliggjøres og trenger en tydeligere posisjon» i: V. Glaser, K.H. Moen, S. Mørreaunet \& F. Søbstad: Barnehagens grunnsteiner. Formålet med barnehagen. 2. utgave. Oslo: Universitetsforlaget.

Thoresen, I.T. (2016). « Verdier og kryssende krav i barnehagen. Lovverk og samfunnsmandat» i Prismet nr. 2/2016 s. 107-117.

Tjora, A. H. (2017). Kvalitative forskningsmetoder i praksis (3. utg. ed.). Oslo: Gyldendal akademisk.

van den Heuvel, A. (2001). Values for a Global Society. London: WACC Publications.

Wolf, K.D. \& Svenning, S.B. (2018). Perspektiver på barns medvirkning i barnehagen. Oslo: Universitetsforlaget. 